\title{
Modelling Determinants of Customer Loyalty in Services Sector across Different Cultural Contexts
}

\author{
Kelvin Lee ${ }^{1}$, Laura Salciuviene ${ }^{2}$ \\ ${ }^{1}$ Nanyang Technological University \\ 42 Nanyang Avenue, Student Service Centre Level 1 \\ 639798 Singapore \\ E-mail.cskelvinlee@ntu.edu.sg \\ ${ }^{2}$ Lancaster University Management School \\ Charles Carter building, Room D08 \\ Lancaster, LA1 4YX, United Kingdom \\ E-mail.l.salciuviene@lancaster.ac.uk
}

cross $^{\text {ref }}$ http://dx.doi.org/10.5755/j01.ee.29.5.17386

\begin{abstract}
Research on customer loyalty in services has regained interest among academics and practitioners alike because of economic value that international service providers can gain across different cultures due to recent developments in communications technology. International service providers have a wider variety of communication channels to use to approach their customers, but they need a better understanding of how their customer loyalty is formed across different cultures. In this conceptual paper, the authors aim to model determinants of customer loyalty and put forward propositions to be empirically tested in further studies. The originality of the paper manifests itself in the theoretical model proposed, which clearly delineates determinants of customer loyalty (i.e., marketing communication channels, perceived service quality and customer satisfaction) and emphasises the importance of strategic decisions about communication channel options to match customer preferences to predict combined effects of customer loyalty across different cultural contexts.
\end{abstract}

Keywords: Customer Loyalty; Customer Loyalty Determinants; International Service Providers; Cross-Cultural Context.

\section{Introduction}

International services industry has continuously been growing and has become an increasingly important part of the worldwide economy (Margetts, 2012; Hummel, Schacht \& Maedche, 2016). With rapid developments of interactive / mobile-based marketing communications, service quality, customer satisfaction and customer loyalty are becoming crucial parameters for a business success in services (Parasuraman \& Grewal, 2000; Caruana, 2002; Aksoy et al., 2012; Zhang, Jin, Wang, Goh \& He, 2016; Bello, Radulovich, Javalgi, Scherer \& Taylor, 2016).

The rapid growth in the information technology sector has created a need for a widespread communication research in today's fast changing environment (Hall, 2015; Tran \& Corner, 2016; Bacile, Fox, Wolter \& Massa, 2017). New technology solutions and process changes are being implemented to enable organizations to conduct businesses more effectively (Preston, 2017). For instance, current technologies might offer a single integrated application to manage all customer interactions across different communication channels (Rapp et al., 2010; JimenezCastillio \& Sanchez-Perez, 2013; Huang \& Liao, 2015; Rondon, Boveda-Lambie \& Neumann, 2017) to improve customer experiences with companies. Subsequently, more satisfied customers are more likely to become regular customers and repurchasing behaviour translates into an economic value for businesses allowing them to maintain their market share and run their businesses profitably in the current highly competitive market.
However, an insufficient assessment of the influence of culture on customer preferences impedes accurate selection of communication channels. Moreover, as markets are becoming more and more geographically integrated, there is a need to better understand communication research that would extend a single country's borders to spot changes in customer preferences and offer an adequate communication for customers (Gevorgyan \& Manucharova, 2009). Cultural variability often leads to the development of differences in customer behaviour within and across national boundaries and provides important explanations for variances in customer preferences and choices (Shaw \& Clarke, 1998; Salciuviene et al., 2005; Reardon et al., 2008; Salciuviene et al., 2010; Qiu et al., 2013).

In recent years, multi-channel customer contacts, such as self-service web chat and social media platforms became important (e.g., Neslin et al., 2006; Cooper et al., 2009; Heinonen \& Michelsson, 2010; Robertson, 2012; Seck \& Philippe, 2013; Fan, Kulkarni, Gormus, Efthymiou, Kalogridis, Sooriyabandara \& Chin, 2013; Lien \& Cao, 2014; Lee, Moon, Kim \& Mun, 2015; Sanghavi, De Mattos \& Salciuviene, 2015; Polp \& Sese, 2016; Sousa, Amorim, Pinto \& Magalhaes, 2016) to improve customer communication with international service providers operating in different cultures. Particularly, when the production of services is associated with communication, customer evaluations of service quality become critical when crossing boundaries (Kanso $\&$ Kitchen, 2004) because not all customers have the same 
Kelvin Lee, Laura Salciuviene. Modelling Determinants of Customer Loyalty in Services Sector across Different...

level of technological skills or prefer the same communication channel across different cultures. Moreover, few attempts have been made to assess this phenomenon cross-culturally (Leonard et al., 2009; Proctor et al., 2011).

Although customer loyalty is becoming an increasingly popular topic among academics and practitioners alike, there is little known about combining customer preferences of communication channels with other determinants in one model. Based on the theoretical development of the model combining the above determinant with the other two, namely, perceived service quality and customer satisfaction, the authors aim to propose the model and put forward three propositions to be tested in future research. The paper aids better understanding of customer loyalty and its determinants and it should be of interest for academics along with international service providers operating internationally as customer loyalty converts into an economic value to firms operating in the services sector across different cultures.

\section{Theoretical Development: Nature of Services, Customer Contact in Services and Services Classification Models}

The nature of the service affects types of contacts and customer service system contacts can be classified as active, passive or both (Mersha, 1990). Other research (Chase, 1978, 1981; Chase, Northcraft \& Wolf 1984; Mersha, 1990; Kinder, 2001; Schmenner, 1986) suggests that the level of customer contact may range from low to high. For instance, the Schmenner's Service Process Matrix (1986) indicates that where contact is low, most tasks are performed in the back office; while, where contact is high the customer is in the direct contact with the service system throughout most of the service delivery process.

The cost involved in the production and delivery of the intended service determines the service operating efficiency (Chase et al. 1984). Typically, this would involve the costs of active contact time, passive contact time and back office task performance based on resource requirements, task complexity and employee skill level needed for the production of each service output. Based on the unit of a service output, Mersha (1990) suggest that the relative weight can be assigned to each type of task (active and passive contact time between the customer and service providers as well as between the customer and the services system). Statistically, Chase (1981) and Chase \& Tansik (1983) suggest that the extent of a contact between the customer and the service facility relative to the total service production time determines the potential operating efficiency of the service facility. Service facility is "classified according to the type and amount of interactions customers have with the service facility" (Chase et al., 1984, p. 543).

Thus:

Potential operating

$$
\text { efficiency }=f\left(1-\frac{\text { customer contact time }}{\text { service creation time }}\right)
$$

Where
Customer contact time refers to the time that the customer has been in a direct physical contact with the service facility.

Service creation time refers to the time needed to perform various tasks required to provide the desired service, including activities performed in the back office.

In services, Chase (1978) defines customer contact as "the physical presence of the customer in the system" (p.138). Chase's (1981) model has been useful for designing, analysing and understanding service providers and further extensions of the model have been offered in the literature due to the insufficient classification of service systems and a lack of the potential to assess service facility effectively (Mersha, 1990; Delone \& McLean, 1992; Soteriou \& Chase, 1998; Kellogg, 2000; Yazici, 2002; Negash et al., 2003; Kumar \& Kumar, 2004; Chase \& Apte, 2007; Zomerdijk \& Voss, 2010). For instance, according to Schmenner (1986), the limitation of Chase's (1981) model is in unclarified definition of a customer contact and insufficient differentiation between services, which primarily require the physical presence of the customer in the service facility and those involving a high degree of interaction and customisation. Therefore, Schmenner (1986) proposed an improved customer contact matrix based on the degree of labour intensity on one axis and the degree of interaction and customisation on the other. The shortcoming of this matrix is its focus on the service process, which requires the customer's physical presence in comparison to those that do not require any physical presence as Mersha (1990) argues that Chase's (1981) definition is rather restrictive since a customer does not always have to be physically present to make a direct contact with a service facility. For example, most activities of tele-banking, insurance or travel services are performed by telephone and other telecommunication systems, therefore, no physical presence of the customer are necessary. Further, Mersha (1990) proposes a broader customer contact definition that incorporates service encounters involving a direct contact, although may not necessarily face-to-face interaction between the customer and the service facility. His new definition addresses this concern: "customer contact refers to a direct encounter between the customer and the service system. This encounter may be face-to-face, either by the customer's presence in the service system or the presence of the service system's representative in the customer's facility, or it may be mediated through the use of communication technologies such as the telephone" (p. 394).

How customer preferences for communication channels could be determined in different cultural contexts?

Culture is important when making decisions about communications between companies and their customers (Kanso \& Kitchen, 2004, Alden et al., 2010, Leonard et al., 2011). Developing a deeper understanding of local culture and evaluating its influences on customer preferences is central to all business across cultures (Shaw \& Clarke, 1998, Leonard et al., 2011) but, particularly, to international service providers (e.g., Salciuviene et al. 2010). 
In cross-cultural research, various elements of culture interact with other external forces and directly or indirectly influence customer satisfaction, which in turn leads to a company's profit. Thereby there is no doubt that culture does play a role and affects how business is conducted across countries (e.g., Kazlauskaite et al., 2009). For this reason, researchers must take into consideration cultural assessment to avoid mistakes across cultures (Kanso \& Kitchen, 2004, Harzing et al., 2005; Leonard et al., 2011).

The approach to the determinants of customer choice of communication channels both within a particular cultural context and across countries takes its point of departure in the culturalist approach, which requires clarification in what culture is, and focuses on the patterns of its manifestation through customer preferences. The authors find inspiration in Geertz's (1973) and Gullestrup's (2001; 2006) definitions and view culture as a configuration of learned behaviour, mainly embodied and transmitted by symbols, which are affected by the collection of learned attitudes, shared by members within a group, and distinguishing one group of members from another. Consequently, in considering the nature of culture and complexity in defining it, our perception of culture refers to patterns of human behaviour and one's perceptions and attitudes that determine human actions, and is thus congruent with the aim of the paper.

Customer communication channels include traditional channels, such as letters, faxes, telephone, face-to-face and newer communication channels such as call centre, service centre, web site and virtual Internet communities. Service providers vary the way they communicate with their customers and how well they use communication channels. However, the way wherein a service company communicates with their customers may not be customers preferred choice of communication and interaction. More importantly, the selected customer communication channel may not be an optimal match to what customers expect from the international service providers. Customers may prefer some communication channels to others either for transaction purposes (e.g., Montoya-Weiss et al., 2003; Gupta et al., 2004; Ansari et al., 2005; Verhoef \& Donkers, 2005; Froehle, 2006; Berger, 2009; Hasouneh \& Alqeed, 2010; Rai et al., 2012; Polo \& Sese, 2016) or for communication purposes (e.g., Koppelman et al., 1977; Mersha, 1990; Moore \& Jovanis, 1987; 1988; Soteriou \& Chase, 1998; Fan et al., 2013; Huang \& Liao, 2015) as well as due to individual differences, such as differences in personal values or different cultural contexts (Harzing et al., 2005; Leonard et al., 2011).

Communications have been the subject of research for many scholars across different disciplines over the years (e.g., Chase, 1978; Mersha, 1990; Delone \& McLean, 1992; Yazici, 2002; Negash et al., 2003; Montoya-Weiss et al., 2003; Gupta et al., 2004; Ansari et al., 2005; Verhoef \& Donkers, 2005; Froehle, 2006; Keller, 2009; Leonard et al., 2011; Reinold \& Tropp, 2012; Maity \& Dass, 2014; Auruskeviciene et al., 2015; Tran \& Corner, 2016; Rondon et al., 2017). For instance, in services field, Moore \& Jovanis (1988) propose a media choice behaviour model, where consumer preferences and choices are made based on knowledge of the communication context, both initiator and recipient of the communication, the alternative media and travel options. In their study, an experiment was used to create realistic scenarios for respondents to rate their media preferences (telephone, mail, internal mail, facsimile, voice mail, electronic mail, courier and telex) and extent of contextual information (communication purpose, urgency, complexity, organisational location and relative status). Specifically, their model comprises two key elements:

(1) The first element refers to the interaction between a company's supply of communication facilities and the demand for communication needs. Moore \& Jovanis (1988) state that their model could address the range of effects on travel and traditional communications markets caused by introducing newer media (electronic mail, teleconferencing and voice messaging) into the workplace. The demand for communication evolves from the organisational structure of the firm, which includes the firm's goals and mission and rules governing individual behaviour. The supply and demand interacts and results in the need for certain quantity and type of communication activity. Some of the communication needs are met by using communication, while others can only be satisfied by physical presence alternatives (for example, face-to-face meeting). Changes may be made to the communication supply to improve communication activities after a careful evaluation of communication outcomes.

According to the authors, an important feature of the model is the feedback from communication to both supply and demand. Communication needs change as change the firm's goals and mission and new communications media become available in the market. Detailed knowledge is required of how the feedback loops operate and what criteria are used to evaluate communication outcomes.

(2) The second element regards the individual's choice of a communication medium in an organisation. This element is based on a model of the customer choice process (Koppelman et al., 1977), modified by Moore \& Jovanis (1988) using their exploratory research findings. The choice is determined by the characteristics of the communication activity and the relationship between the communication initiator and its recipient.

It is assumed that there are certain attributes of the communication situation, such as urgency of the communication and personal needs (desire to communicate using a familiar medium). The initiator is also assumed to have knowledge of the characteristics of medium alternatives in the form of cognitive, attribute-based or affective expectations.

The suitability of each medium for the recipient / communicator is then assessed. An individual would compare expectations about each medium with the relative importance of attributes and personal needs in a specific situation to evaluate which alternatives are the best match. This process results in the formation of communication channel preferences, while the actual choice is determined by the influence of situational constraints on an individual's media preferences. Their experimental results suggest that ease of use, speed and reliability are important factors to explain consumer media choices and conclude that communication media choice behaviour is very context-dependent. 
Kelvin Lee, Laura Salciuviene. Modelling Determinants of Customer Loyalty in Services Sector across Different...

What are the consequences of identifying customer preferences by international service Providers in different contexts?

The literature suggests that a deep analysis of customer preferences and purchasing habits forms the essence of customer relationship management and results in the change of a company's philosophy from a product centric to a customer centric (Bose, 2002; Wilson et al., 2002; Payne \& Frow, 2005). Thus, most service providers gather data intelligence and use IT services to analyse their sophisticated data for customer relationship management (Herceg \& Madison, 2004) comprising such factors as improvements in service quality, increased customer satisfaction and loyalty.

Previous research has linked service quality, communication time and intimacy elements (Kellogg \& Chase, 1995; Soteriou \& Chase, 1998). Later, Cronin \& Taylor (1992) investigated the relationship between service quality, customer satisfaction and purchase intention and found that service quality is an antecedent of customer satisfaction, while customer satisfaction has a significant effect on purchase intention. Also, service quality leads to stronger relationships with the service providers resulting in customer loyalty in the form of repeat purchase behaviour (e.g., Storbacka, Stranvik \& Gronroos, 1994 Ivanauskiene et al., 2013). Customer loyalty could be increased more effectively through multi-channel customer communications (Peppard, 2000).

In the web-based environment, Negash et al. (2003) conducted a study to test their proposed model with three quality dimensions and user satisfaction they adapted from previous studies by Pitt, Watson \& Kavan (1995) and Delone \& McLean (1992). These authors suggest that the quality of a web-based customer support system involves the overall quality of information it supplies, the service it provides and the characteristics of the support system itself, such as interactivity and accessibility. The findings of their study confirm that the system quality is associated with user satisfaction, that is, users are satisfied when the system quality meets their expectation, but this relationship is context dependent.

\section{Where Do We Go From Here? Theoretical Model and Propositions}

With the advances in digital technology (Preston, 2017), international service providers use diverse and more sophisticated communication channels to reach, communicate and interact with their customers.

We use Classification Theory to propose the theoretical model comprising those four important elements that may influence customer preferred communication channels, positively affecting service quality, satisfaction and customer loyalty for specific service providers. Classification Theory explains that knowledge about things needs to be organised into categories.

In the theoretical model, we put forward the following key elements: (1) service provider decisions, (2) customer profile / expectations and (3) customer preferred communication channels, which might promote or impede the following consequences for service provider: (4a) service quality and (4b) customer satisfaction influencing (4c) customer loyalty (Figure 1).

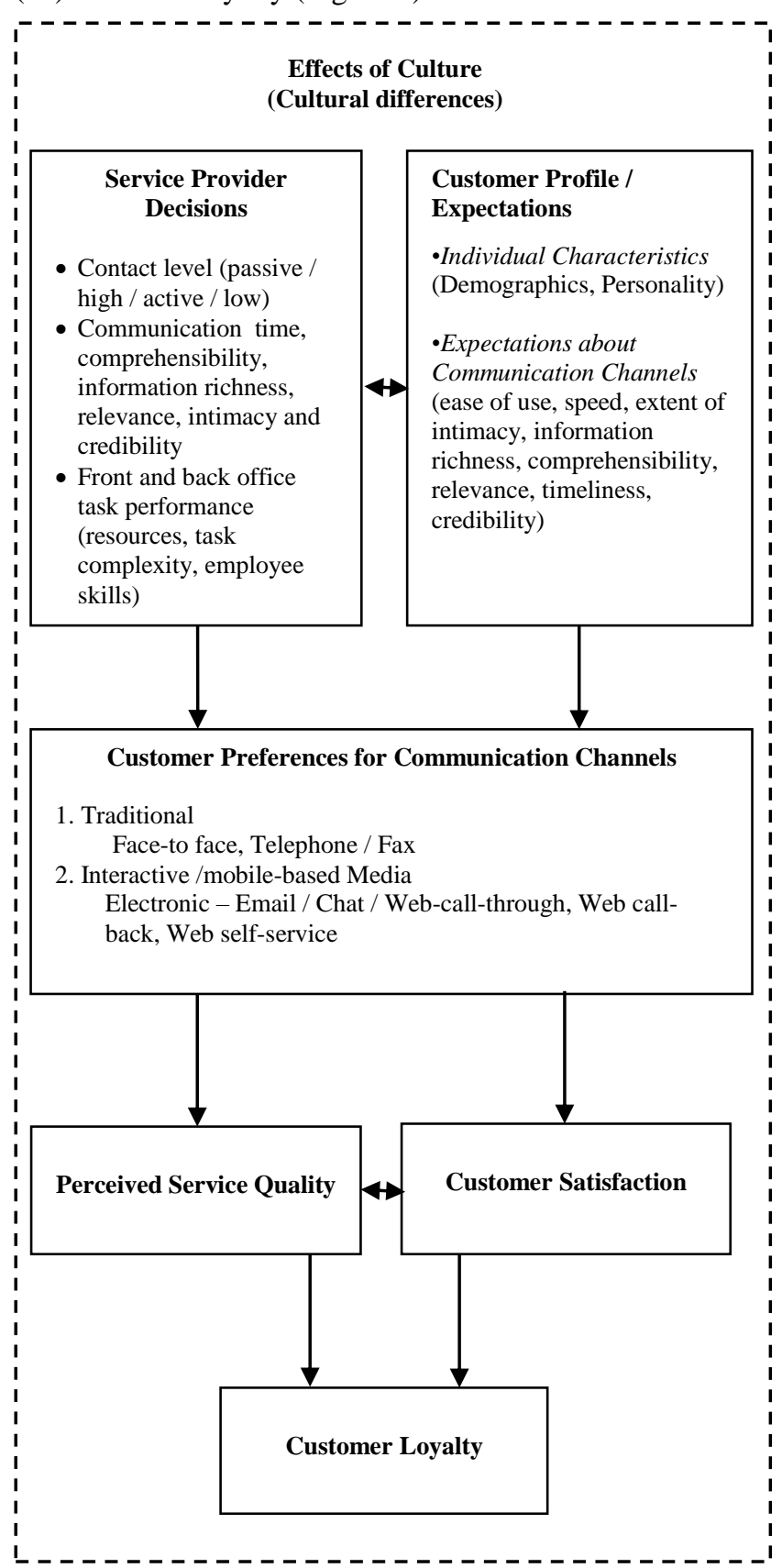

Figure 1. A Theoretical Model of Determinants and Consequences of Customer Preferred Communication Channels

\section{Effects of Culture}

Not only do international service providers have to assess market opportunities, and examine future trends for long-term strategies, but they also need to account for the local context when offering their services. This requires a deeper understanding of how customers choose their preferred communication channel to offer those communication channels that will have the highest effectiveness for different customers within a particular cultural context.

Culture affects customer individual characteristics as well as customer preferences for different communication channels. Customer expressions of likes and dislikes 
(cultural principles) that lead to specific communication choices distinguish customers from each other. Therefore, customer likes and dislikes and the market segments they define have important implications for international marketers (Arnould et al., 2004).

Lively debates are going on among scholars as to whether cultural studies must be treated as a unique whole (Gullestrup, 2006), or whether cultural factors observed across cultures could be identified as universals (Hofstede, 2001). Thus, by knowing the values, or groups of values of a particular culture, and comparing them to those of another, we can relatively predict behavioural, attitudinal and other differences. That is, it is possible to estimate the extent to which culture will influence choice of marketing communication effectiveness across cultures. Moreover, scholars argue, that the use of culture in explaining variation across countries depends on how culture is treated (Mockaitis, 2002) and findings depend on conceptualising culture (Cavusgil \& Das, 1997; Samiee \& Jeoung, 1994; Sekaran, 1983) and a priori definitions of the cultural groups being studied or identification of a 'cultural' rather than 'national' unit (Samiee \& Jeoung, 1994; Lenartowicz \& Roth, 1999).

Culture interacts with both factors: organisational decisions of international service providers and customer profile / expectations that, in turn, influence customer preferences for communication channels and affect customer satisfaction, perceived service quality and loyalty. In other words, international service providers have to get acquainted with local cultures to ensure a proper choice of communication channels has been offered to its consumers. By allowing customers to select the most relevant communication channels to reach the international service provider, perceived service quality increases, customers become more satisfied with the international service provider, their loyalty increases, thus, ensuring higher profits and market share maintenance for international service providers in the long-term.

In the emerging view of culture and customer preferences, international service providers must assess how to align their communication channels with cultural principles. To successfully communicate with their customers, marketing communications should be built on cultural features. If we agree that individuals' preferences are determined at least in part by his or her culture, we can conclude that customers choose specific communication channels corresponding with their own culture. Likewise, cultural variability often leads to the development of differences in usage of different kinds of communication channels within and across national borders and provides important explanations for variances in customer preferred choices.

\section{Decisions by International Service Providers}

An important determinant for selecting specific communication channels refers to connectivity, defined by the costs of establishing a communication link with customers. For example, the cost of connectivity is smaller when using the Internet than the telephone. Also, the desirable contact level (high - active versus low - passive contact) should be taken into consideration when designing the communication channels by international service provider. A desirable contact level also specifies the duration of communication time, extent of intimacy the service encounter should receive and information quality, which will affect the expectations of the customers about the comprehensibility, relevance or credibility.

Communication time refers to the total time spent for communication between the customer and the international service provider. Intimacy is the extent of perceived level of individual care and attention given by staff from the international service provider. In most situations, customers do have an acceptable time range and level of intimacy that depends on prior expectations and complexity of the service offered. Information richness refers to the level of information quality in terms of informativeness or entertainment, information delivery, information access, information sharing and information use.

International service providers have to make the above decisions taking into account front and back office task performance in terms of resource requirements, complexity of tasks and employee skills to ensure timely and adequate response to customers through a variety of communication channels.

\section{Customer Profile and Expectations}

Customer experiences are formed when encountering the international service providers through their preferred communication channels to interact with the company. The process of interaction establishes a dialogue between a customer and the service company employees and gives a start to a rudimentary relationship. The proposed model, therefore, recognizes the customer profile through individual characteristics and expectations about different communication channels to be used for contacting the international service provider. First, individual differences in demographics such as gender, age, education, income, region and personality influence the attractiveness of different communication channels. Second, each channel will be assessed for its suitability to match customer expectations, for instance, customer would expect their communication channel to be relevant and credible. The result of this process is the formation of channel preferences, but the actual choice might also be contingent upon ease of use, relevant speed and reasonable communication time that a specific communication channel might offer in addition to its comprehensibility or intimacy.

Customer Preferred Communication Channels and Consequences for International Service Providers

In this paper, we hold that customer preferences for communication channels are determined by international service provider decisions, customer profile and their expectations about specific channels of communication.

The theoretical model proposes the consequences for international service providers due to their effort to better understand their customer choices. Through a successful communication with customers, international service providers aim to create and sustain positive customer experiences as improved relationship quality leads to longterm relationships with customers (Auruskeviciene et al., 2010). 
Kelvin Lee, Laura Salciuviene. Modelling Determinants of Customer Loyalty in Services Sector across Different...

According to the model, customer loyalty depends on a strategically well selected communication channels that international service providers might offer to match their customer preferences. Signalling Theory could provide an explanation for a positive effect of customer preferred communication channels to communicate and interact with the international service provider on evoking positive consequences, such as increased perceived service quality, enhanced customer satisfaction and increased loyalty to the international service provider. According to this theory, two parties participate in the information exchange with each other. Usually those two parties use different means of communication for sending and receiving the information they aim to exchange. Thus, our model suggests that international service providers would need to offer both traditional and newer communication channels to their customers to in different cultural settings. Depending on the different cultural contexts, customer profile and expectations, each customer would then choose the most relevant communication channel to start a communication with the international service provider be it a simple question they wish to ask about specific services or a more serious matter to resolve by customer services. By offering matching communication channels, international service providers could improve their service offerings and increase their perceived service quality, resulting in higher customer satisfaction and enhanced customer loyalty.

\section{Propositions}

Based on the above discussion, three propositions are put forward by the authors to test the following effects:

Pla: Decisions by international service providers about communication channels they use to promote customer loyalty will positively affect expectations about communication channels by their customers in different cultural environments.

P1b: Customer expectations about communication channels will positively influence international service provider decisions about communication channels they use to promote customer loyalty across cultures.

P1c: Decisions of international service providers about communication channels they use across cultures to promote customer loyalty and customer expectations about communication channels will positively influence their communication channel preferences.

P2: Customer preferred communication channels across cultures will positively influence perceived service quality and customer satisfaction.

P3a: Customer perceived service quality will positively influence customer satisfaction in different cultural contexts.

P3b: Customer satisfaction will positively influence customer perceived service quality in different cultural contexts.
P3c: Customer perceived service quality and customer satisfaction in different cultural contexts will positively influence customer loyalty.

\section{Conclusion}

This contribution offers a theoretical model of customer loyalty determinants. It suggests propositions signifying that customer loyalty in the services sector across different countries could be better understood by taking into account cross-cultural influences and modelling combined effects of service provider decisions how to promote loyalty in different cultural contexts, customer expectations about communication channels, customer preferred communication channels, customer perceived service quality and customer satisfaction. Further, our theoretical contribution offers the means for international service providers to identify target audiences more precisely. Apart from using common demographic variables as key segmenting variables to define the target audience, the model proposes an additional segmentation variable, that is, customer expectations about communication channels in different cultural contexts.

When studying cross-cultural customer preferences, the definition of culture authors work with is not only culturebased, but also covers both cognitive and behavioural elements and consists of two parts - what culture is and how it manifests itself. Therefore, the authors of this paper hold that international service providers could identify their potential target audiences more sensibly if a combination of macro (demographic variables) and micro (expectations about communication channels) segmentation variables across different countries to match the conceptualisation of culture in cross-cultural research would be used. Our proposed model should be useful to service firms that are interested in sustaining relationships with their customers and earn their customer loyalty across cultures.

Research on communication channels and the usage of both traditional and interactive / mobile-based medium among international service providers has increased over the last years due to their contribution to customer satisfaction, customer loyalty and acquiring new customers in different markets. Although marketing academics and practitioners agree that identifying suitable communication channels is vital for a company's long term success with its customers, there is an on-going debate in the literature whether this integrated multi-channel communication platform is right for the customers and how effective it is for international service providers to promote and sustain customer loyalty that could become economically viable to firms, especially in services sector. It is our expectation that this model will be of interest to practitioners as the combined effects of customer loyalty determinants may lead to a long-term relationships with service firm customers.

\section{Future Research}

Our theoretical model and propositions call for further empirical tests of the effects of customer loyalty determinants in services sector across different cultural contexts. Several service sectors, especially those 
attributed to social marketing areas, across diverse cultural contexts may be used to empirically validate the model and limitations when attempting to generalise findings have to be outlined. Such empirical studies in the above sector would add to the investigation of customer loyalty determinants in services.

One of those services sectors could be services firms selling organic food to customers with intention to care for their healthier lifestyles and preserving the nature by growing food without any preservatives that might harm the environment.

Another services sector could be service firms operating in second-hand goods industry and organizing charity events for advantaged or disadvantaged citizens. For instance, services firms organizing charity events or selling second-hand goods in charity shops could be investigated in greater depth to better understand customer preferred marketing communication channels to better engage with those services firms. Specifically, customer profile and expectations from channels directing their communication channel preferences along with decisions by international service providers to match those customer choices should result in higher customer perceived service quality. Further, by offering the most relevant communication channels to their customers, international service providers are more likely to generate higher satisfaction among their customers and encourage repurchasing behaviour that would promise a constant market share with a tangible economic value for international service providers to run their businesses across cultures more profitably and enabling those services firms to donate part of their profits to less advantaged customers. Next, it might be important to monitor changes of customer preferences for specific communication channels at different customer relationship stages with charity service providers to provide recommendations for international service providers of charitable services on how to adjust their communication channel strategies accordingly to foster customer relationships with the company and promote loyalty behaviour of their customers across different cultures.

\section{References}

Aaker, D. Kumar, V., Leone, R., \& Day, G. (2012). Marketing research. New York, Willey.

Abbasi M. R., \& Moezzi H. (2012). Exploring of relationship between corporation social responsibility and loyalty and satisfaction customer and the facilitating role of Aavertising on it. (Case study Shirazit Co.). International Journal of Academic Research in Business and Social Sciences, 2(1), 460-468.

Aksoy, L., Buoye, A., Aksoy, P., Lariviere, B., \& Keiningham, T.L. (2012). A cross-national investigation of the satisfaction and loyalty linkage for mobile telecommunications services across eight countries. Journal of Interactive Marketing, 27(1), 74-82. https://doi.org/10.1016/j.intmar.2012.09.003

Alden, D.L., He, Y., \& Chen, Q. (2010). Service recommendations and customer evaluations in the international marketplace: cultural and situational contingencies. Journal of Business Research, 63(1), 38-44. https://doi.org/10.1016/j.intmar.2012.09.003

Ansari, A., Mela, C., \& Neslin, S. (2005) Customer channel migration. Teradata Center, Duke University, Durham, NC. Working Paper, Paper Series No 13.

Arnould, E., Price, L., \& Zinkhan, G. (2004) Consumers. 2nd Ed. Irwin, USA: New York: McGraw-Hill:

Auruskeviciene, V., Butkeviciene, J., \& Salciuviene, L. (2015). Revisiting the role of traditional, electronic and mobilebased communication channels in the pharmaceutical industry of Lithuania. Engineering Economics, 26 (5), $541-$ 550 .

Auruskeviciene, V., Salciuviene, L., \& Skudiene, V. (2010). The relationship quality effect on customer loyalty. Pecvnia, 10, 23-36. https://doi.org/10.18002/pec.v0i10.637

Bacile, T. J., Fox, A. K., Wolter, J. S., \& Massa, F. (2017). Structured abstract: all online complaints are not created equal, Corporate Social Media Pages as Customer Service Channels. In Creating Marketing Magic and Innovative Future Marketing Trends (pp. 23-28). Springer, Cham. https://doi.org/10.1007/978-3-319-45596-9_5

Baden, D., Harwood, I., \& Woodward, D. (2011). The effects of procurement policies on downstream CSR activity: content analytic insights into the views and actions of SME owner-manager. International Small Business Journal, 29, 259-277. https://doi.org/10.1177/0266242610375770

Bello, D. C., Radulovich, L. P., Javalgi, R. R. G., Scherer, R. F., \& Taylor, J. (2016). Performance of professional service firms from emerging markets: Role of innovative services and firm capabilities. Journal of World Business, 51(3), 413-424. https://doi.org/10.1016/j.jwb.2015.11.004

Berger, S. V. (2009). Self-service technology for sales purposes in branch banking: the impact of personality and relationship on customer adoption. International Journal of Bank Marketing, 27(7), 488-505. https://doi.org/10.1108/02652320911002322 
Kelvin Lee, Laura Salciuviene. Modelling Determinants of Customer Loyalty in Services Sector across Different...

Bose, R. (2002) Customer relationship management: key components for IT success. Industrial Management and Data Systems, 102(2), 87-97. https://doi.org/10.1108/02635570210419636

Caruana, A. (2002). Service loyalty: the effects of service quality and the mediating role of customer satisfaction. European Journal of Marketing, 36(7-8), 811-828. https://doi.org/10.1108/03090560210430818

Cavusgil, S. T., \& Das, A. (1997). Methodological issues in empirical cross-cultural research: a survey of the management literature and a framework. Management International Review, 37, 71-96.

Chase, R. B., \& Tansik, D. A. (1983) .The customer contact model for organization design. Management Science, 29(9), 1037-1050. https://doi.org/10.1287/mnsc.29.9.1037

Chase, R. B. (1978). Where does the customer fit in a service operation? Harvard Business Review, 56(6), $137-142$.

Chase, R. B. (1981). The customer contact approach to services: theoretical bases and practical extensions. Operations Research, 29(4), 698-706. https://doi.org/10.1287/opre.29.4.698

Chase, R. B., Northcraft, G. B. \& Wolf, G. (1984). Designing high-contact service systems: application to branches of a savings and loan. Decision Sciences, 15(4), 542-556. https://doi.org/10.1111/j.1540-5915.1984.tb01241.x

Chase, R.B., \& Apte, U.M. (2007). A history of research in service operations: what's the big idea? Journal of Operations Management, 25(2), 375-386. https://doi.org/10.1016/j.jom.2006.11.002

Cooper, V., Lichtenstein, Sch., \& Smith, R. (2009). Successful web-based IT support services: service provider perceptions of stakeholder-oriented challenges. E-services and Mobile Applications, 1(1), 1-20. https://doi.org/10.4018/jesma.2009092201

Cronin, J. J., \& Taylor, S. A. (1992). Measuring service quality: a re-examination and extension. Journal of Marketing, 56(3), 55-68. https://doi.org/10.1177/002224299205600304

Delone, W. H., \& McLean, E. R. (1992). Information systems success: the quest for the dependent variable. Information Systems Research, 3(1), 60-95. https://doi.org/10.1287/isre.3.1.60

Fan, Z., Kulkarni, P., Gormus, S., Efthymiou, C., Kalogridis, G., Sooriyabandara, M., \& Chin, W. H. (2013). Smart grid communications: Overview of research challenges, solutions, and standardization activities. IEEE Communications Surveys \& Tutorials, 15(1), 21-38.

Froehle, C. M. (2006). Service personnel, technology and their interaction in influencing customer satisfaction. Decision Sciences, 37(1), 5-38. https://doi.org/10.1109/SURV.2011.122211.00021

Geertz, C. (1973). The interpretation of cultures. Basic Books, USA: New York.

Gevorgyan, G., \& Manucharova, N. (2009). Does culturally adapted online communication work? A study of American and Chinese internet users' attitudes and preferences toward culturally customized web design elements. Journal of Computer-Mediated Communication, 14(2), 393-413. https://doi.org/10.1111/j.1083-6101.2009.01446.x

Gullestrup, H. (2001). The complexity of intercultural communication in cross-cultural management. 5th NIC Ssymposium on Anthropological Linguistics 27 Intercultural Communication-Business and the Internet, Gothenburg, Sweden.

Gullestrup, H. (2006). Cultural analysis. Aalborg: Aalborg University Press, Denmark.

Gupta, A., Su, Bo-Ch., \& Walter, Z. (2004). An empirical study of consumer switching from traditional to electronic channels: a purchase-decision process perspective. International Journal of Electronic Commerce, 8(3), $131-161$. https://doi.org/10.1080/10864415.2004.11044302

Hall, J. (2015). 7 PR trends you need to know in 2016 [accessed on 10 December, 2016 at http://www.forbes.com/sites/johnhall/2015/12/13/7-pr-trends-you-need-to-know-in-2016/\#6be80a801b6b]

Harzing, A. W., Salciuviene, L., and 31 country collaborators (2005). The use of English questionnaires in cross-national research: does cultural accommodation obscure national differences? International Journal of Cross-Cultural Management, 5, 2, 225-229. https://doi.org/10.1177/1470595805054495

Hasouneh, A. B. I., \& Alqeed, M. A. (2010). Measuring the effectiveness of e-mail direct marketing in building customer relationship. International Journal of Marketing Studies, 2(1), 48-64. https://doi.org/10.5539/ijms.v2n1p48

Heinonen, K., \& Michelsson, T. (2010). The use of digital channels to create relationships. International Journal of Internet Marketing and Advertising, 6(1), 1-21. https://doi.org/10.1504/IJIMA.2010.030430

Herceg, P., \& Madison, D. (2004). Multichannel customer contact management. IT Professional, 6(3), 33-40. https://doi.org/10.1109/MITP.2004.18

Hofstede, G. (2001). Culture's consequences: comparing values, behaviours, institutions, and organizations across nations. 2nd Ed, London UK: Sage Publications. 
Huang, T. L., \& Liao, S. (2015). A model of acceptance of augmented-reality interactive technology: the moderating role of cognitive innovativeness. Electronic Commerce Research, 15(2), 269-295. https://doi.org/10.1007/s10660-0149163-2

Hummel, D., Schacht, S., \& Maedche, A. (2016). Determinants of multi-channel behavior: exploring avenues for future research in the services industry.

Ivanauskiene, N., Salciuviene, L., \& Auruskeviciene, V. (2013). Perceived value drivers of customer loyalty in an emerging market. BAM Conference Proceedings.

Jimenez-Castillio, D., \& Sanchez-Perez, M. (2013). Nurturing employees' market knowledge absorptive capacity through unified internal communication and integrated information technology. Information and Management, 50(2), 76-86. https://doi.org/10.1016/j.im.2013.01.001

Kanso, A., \& Kitchen, P. J. (2004). Marketing consumer services internationally. Marketing Intelligence and Planning, 22(2/3), 201-215. https://doi.org/10.1108/02634500410525869

Kazlauskaite, R., Buciuniene, I., Turauskas, L., \& Salciuviene, L. (2009). A comparative study of employee empowerment in Danish and Lithuanian hotels. Transformations in Business and Economics, 8(17), 66-85.

Keeling, K. Salciuviene, L., \& Tiasuwan, P. (2013). Interactive websites: the effects of social presence on customer decisions in the online luxury goods sector. EMAC Conference Proceedings.

Keller, K. L. (2009). Building strong brands in a modern marketing communications environment. Journal of Marketing Communications, 15(2/3), 139-155. https://doi.org/10.1080/13527260902757530

Kellogg, D. L., \& Chase R. B. (1995). Constructing an empirically derived measure for customer contact. Management Science, 41(11), 1734-1749. https://doi.org/10.1287/mnsc.41.11.1734

Kellogg, D. L. (2000). A customer contact measurement model: an extension. International Journal of Service Industry Management, 11(1), 26-44. https://doi.org/10.1108/09564230010310277

Kinder, T. (2001). The use of call centres by local public administration. Futures, 33(10), 837-860. https://doi.org/10.1016/S0016-3287(01)00022-2

Koppelman, F. S., Hauser, J. R., \& Tybout, A. M. (1977). Preliminary analysis of perception, preferences, beliefs, and usage of transportation services for travel to downtown. Transportation Center Northwestern University: Evanston, IL.

Kumar, R., \& Kumar, U. (2004). A conceptual framework for the development of a service delivery strategy for industrial systems and products. Journal of Business \& Industrial Marketing, 19(5), 310-319. https://doi.org/10.1108/0 8858620410549938

Lee, D., Moon, J., Kim, Y. J., \& Mun, Y. Y. (2015). Antecedents and consequences of mobile phone usability: Linking simplicity and interactivity to satisfaction, trust, and brand loyalty. Information \& Management, 52(3), $295-304$. https://doi.org/10.1016/j.im.2014.12.001

Lenartowicz, T., \& Roth, K. (1999). A framework for culture assessment. Journal of International Business Studies, 30, 781-798. https://doi.org/10.1057/palgrave.jibs.8490839

Lennon, R., \& Harris J. (2002). Customer service on the web: a cross-industry investigation. Journal of Targeting, Measurement and Analysis for Marketing, 10(4), 325-338. https://doi.org/10.1057/palgrave.jt.5740057

Leonard, K. M., Van Scotter, J. R., Pakdil, F. with Chamseddine, N. J., Mockaitis, A. I., Salciuviene, L., Surkiene, G., Tsai, F. S., Wu, L. L., Esatoglu, E., Koyuncu, M., Gumus, M., \& Oktem, K. (2009). Culture and communication: cultural variations and media effectiveness. Administration and Society, 41(7), 850-877. https://doi.org/10.1177/0095399709344054

Leonard, K. M., Van Scotter, J. R., Pakdil, F., with Chamseddine, N. J., Mockaitis, A. I., Salciuviene, L., Surkiene, G., Tsai, F. S., Wu, L. L., Esatoglu, E., Koyuncu, M., \& Oktem, K. (2011). Examining media effectiveness across cultures and national borders: a review and multilevel framework. International Journal of Cross Cultural Management, 11(1), 83-103. https://doi.org/10.1177/1470595810389790

Lien, C. H., \& Cao, Y. (2014). Examining WeChat users' motivations, trust, attitudes, and positive word-of-mouth: evidence from China. Computers in Human Behavior, 41, 104-111. https://doi.org/10.1016/j.chb.2014.08.013

Maity, M., \& Dass, M. (2014). Consumer decision-making across modern and traditional channels: E-commerce, mcommerce, in-store. Decision Support System, 61, 34-46. https://doi.org/10.1016/j.dss.2014.01.008

Margetts, H. Z. (2012). The internet and public policy. Policy \& Internet, 1(1), 1-21. https://doi.org/10.2202/19442866.1029 
Kelvin Lee, Laura Salciuviene. Modelling Determinants of Customer Loyalty in Services Sector across Different...

Mersha, T. (1990). Enhancing the customer contact model. Journal of Operations Management, 9(3), $391-405$. https://doi.org/10.1016/0272-6963(90)90162-7

Mockaitis, A. (2002). The influence of national cultural values on management attitudes: a comparative study across three countries. Unpublished Doctoral Dissertation, Vilnius, Lithuania: Vilnius University.

Montoya-Weiss, M. M., Voss, G. B., \& Grewal, D. (2003). Determinants of online channel use and overall satisfaction with a relational multichannel service provider. Journal of the Academy of Marketing Science, 31(4), 448-458. https://doi.org/10.1177/0092070303254408

Moore, A., \& Jovanis P. P. (1987). Perceptions of new electronic media for business communication. Transportation Research: Part A, 14(4), 329-344.

Moore, A., \& Jovanis P. P., (1988). Modelling media choices in business organisations: implications for analysing telecommunications-transportation interactions, Transportation Research: Part A, 20(4), $257-273$. https://doi.org/10.1016/0191-2607(88)90004-0

Negash, S. D., Ryan, T., \& Igabaria, M. (2003). Quality and effectiveness in Web-based customer support systems. Information and Management, 20(9), 1-12. https://doi.org/10.1016/S0378-7206(02)00101-5

Neslin, S. A., Grewal, D., Leghorn, R., Shankar, V., Teerling, M. L., Thomas, J. S., \& Verhoef, P. C. (2006). Challenges and opportunities in multichannel customer management. Journal of Service Research, 9(2), 95-112. https://doi.org/10.1177/1094670506293559

Parasuraman, A., \& Grewal, D. (2000). The impact of technology on the quality-value-loyalty chain: a research agenda. Journal of the Academy of Marketing Science, 28(1), 168-174. https://doi.org/10.1177/0092070300281015

Payne, A., \& Frow, P. (2005). A strategic framework for customer relationship management. Journal of Marketing, 69(4), 167-176. https://doi.org/10.1509/jmkg.2005.69.4.167

Pitt, L. F., Watson, R. T., \& Kavan C. B. (1995) Service quality: a measure of information systems effectiveness. MIS Quarterly, 19(2), 173-187. https://doi.org/10.2307/249687

Polo, Y., \& Sese, F. J. (2016). Does the nature of the interaction matter? Understanding customer channel choice for purchases and communications. Journal of Service Research, 19(3), 276-290. https://doi.org/10.1177/10 94670516645189

Preston, R. (2017). Top 10 strategic CIO priorities for 2017. Forbes, [accessed 21 January 2017 at http://www.forbes.com].

Proctor, R. W., Nofa, S. Y., Yiha, Y. Balasubramanianb, P. Busemeyerc, J. R., Carayond, P., Chiue, Ch-Y., Farahmanda, F., Gonzalezf, C., Gorea, J., Landrya, S. J., Lehtoa, M., Raug, P. L., Rouseh, W., Tayi, L., Kim-Phuong L. Vuj, Eun Wooa, S., \& Salvendyag, G. (2011). Understanding and improving cross-cultural decision making in design and use of digital media: a research agenda. International Journal of Human-Computer Interaction, 27(2), 151-190. https://doi.org/10.1080/10447318.2011.537175

Qiu, L.,Lin, H., \& Leung, A. K. (2013). Cultural differences and switching of in-group sharing behavior between an American (Facebook) and a Chinese (Renren) social networking site. Journal of Cross-Cultural Psychology, 44(1), 106-121. https://doi.org/10.1177/0022022111434597

Rai, A., Pavlou, P. A., Im, G., \& Du, S. (2012). Interfirm IT capability profiles and communications for co-creating relational value: evidence from the logistics industry. MIS Quarterly, 36(1), 233-262. https://doi.org/10.2 $307 / 41410416$

Rapp, A., Trainor, K. J., \& Agnihorti, R. (2010). Performance implications of customer-linking capabilities: examining the complementary role of customer orientation and CRM technology. Journal of Business Research, 63(11), 12291236. https://doi.org/10.1016/j.jbusres.2009.11.002

Reardon, J, Auruskeviciene, V., Salciuviene, L., McCorkle D., \& Skudiene, V. (2008). The effect of culture on consumer intellectual property theft: an exploratory analysis. In Fuxman, L. Delener, N., Lu, V. and River-Solis (eds.). Evolution and Revolution in the Global Knowledge Economy: Exchanging Innovation and Competitiveness Worldwide (pp. 917-922), Global Business and Technology Association.

Reinold, T., \& Tropp, J. (2012) Integrated marketing communications: how can we measure its effectiveness? Journal of Marketing Communications, 18(2), 113-132. https://doi.org/10.1080/13527266.2010.489334

Robertson, N. (2012). Self-service technology complaint channel choice: exploring consumers' motives. Managing Service Quality, 22(2), 145-164. https://doi.org/10.1108/09604521211218963 
Rondon, C., Boveda-Lambie, A. M., \& Neumann, D. (2017). Structured abstract: consumer's communication channel preferences (high-stake vs. low-stake brands). In Creating Marketing Magic and Innovative Future Marketing Trends (pp. 205-209). Springer, Cham. https://doi.org/10.1007/978-3-319-45596-9_42

Salciuviene, L., Auruskeviciene, V., \& Lydeka, Z. (2005). An assessment of various approaches for cross-cultural consumer research. Problems and Perspectives in Management, 1(3), 147-159.

Salciuviene, L., Ghauri, P., Streder, R. S., \& De Mattos, C. (2010). Do brand names in a foreign language lead to different brand perceptions? Journal of Marketing Management, 26(11\&12), 1037-1056. https://doi.org/10.1080/0267257 X.2010.508976

Samiee, S., \& Jeoung, I. (1994). Cross-cultural research in advertising: an assessment of methodologies. Journal of the Academy of Marketing Science, 22, 205-217. https://doi.org/10.1177/0092070394223002

Sanghavi, N., De Mattos, C., \& Salciuviene, L. (2015). The role of online reviews in services sector and implications for services firms. World Marketing Congress (WMC).

Schmenner, R. W. (1986). How can service businesses survive and prosper? Sloan Management Review, $27(3), 21-32$.

Seck, A. M., \& Philippe, J. (2013). Service encounter in multi-channel distribution context: virtual and face-to-face interactions and consumer satisfaction. The Service Industries Journal, 33(6), 565-579.

Sekaran, U. (1983). Methodological and theoretical issues and advancements in cross-cultural research. Journal of International Business Studies, 14, 61-73.

Shankar, V., Smith, A., \& Rangaswamy, A. (2003). The relationship between customer satisfaction and loyalty in online and offline environments. International Journal of Research in Marketing, 20(2), 153-175.

Shaw, D. S., \& Clarke, I. (1998). Culture, consumption and choice: towards a conceptual relationship. Journal of Consumer Studies and Home Economics, 22, 163-168.

Smith, A. K., Bolton, R. N., \& Wagner, J. (1999). A model of customer satisfaction with service encounters involving failure and recovery. Journal of Marketing Research, 36(3), 356-372.

Soteriou, A. C., \& Chase, R. B. (1998). Linking the customer contact model to service quality. Journal of Operations Management, 16(4), 495-508.

Sousa, R., Amorim, M., Pinto, G. M., \& Magalhaes, A. (2016). Multi-channel deployment: a methodology for the design of multi-channel service processes. Production Planning \& Control, 27(4), 312-327.

Storbacka, K., Stranvik, T., \& Gronroos, C. (1994). Managing customer relationships for profit: the dynamics of relationship quality. International Journal of Service Industry Management, 5(5), 21-38.

Tran, H. T. T., \& Corner, J. (2016). The impact of communication channels on mobile banking adoption, International Journal of Bank Marketing, 34(1), 78-109.

Verhoef, P. C., \& Donkers, B. (2005). The effect of acquisition channels on customer loyalty and cross-buying. Journal of Interactive Marketing, 19(2), 31-43.

Wilson, H., Daniel, E., \& McDonald, M. (2002). Factors for success in customer relationship management (CRM) systems. Journal of Marketing Management (18), 193-219.

Yazici, H. J., (2002). The role of communication in organisational change: an empirical investigation. Information and Management, 39(7), 539-552.

Zeithaml, V., Bitner, V., \& Gremler, D. (2012). Services marketing: integrating customer focus across the firm. London: McGraw-Hill.

Zhang, M., Jin, B., Wang, G. A., Goh, T. N., \& He, Z. (2016). A study of key success factors of service enterprises in China. Journal of Business Ethics, 134(1), 1-14.

Zomerdijk, L. G., \& Voss, Ch. A. (2010). Service design for experience-centric services. Journal of Service Research, $13(1), 67-82$.

The article has been reviewed.

Received in January, 2017; accepted in December, 2018. 